\title{
Ultrasound-Guided Aspiration Therapy for Surgical Site Infection After Spinal Surgery: A Report of three Cases
}

\author{
Meirong Wang, Jiaying Chen, Li jing and Chuiliang Liu* \\ Department of Anesthesiology, Foshan Fosun Chancheng Hospital, Foshan 528031, Guangdong, China \\ *Corresponding author: Liu Chuiliang, Department of Anesthesiology, Foshan Fosun Chancheng Hospital, Foshan \\ 528031, Guangdong, China
}

\section{ARTICLE INFO}

Received: 幽 September 25, 2021

Published: 幽 October 06, 2021

Citation: Meirong Wang, Jiaying Chen, Li jing, Chuiliang Liu. Ultrasound-Guided Aspiration Therapy for Surgical Site Infection After Spinal Surgery: A Report of three Cases. Biomed J Sci \& Tech Res 39(2)-2021. BJSTR. MS.ID.006275.

Abbreviations: SSI: Surgical Site Infection; VSD: Vacuum Sealing Drainage; WBC: White Blood Cell Count; ESR: Erythrocyte Sedimentation Rate; TLF: Thickening of Ligamentum Flavum; ESM: Erector Spine Muscle

\section{ABSTRACT}

Backgroud: Postoperative surgical site infection in the lumbar spine is a wellrecognized complication after surgery. With the prevalence of antibiotic-resistant organisms, the prevention and treatment of infection has become even more difficult and challenging, particularly in those patients with spinal instrumentation.

Case/Intervention: The first patient was a 79-year-old woman with increased lowback pain in 15 days after spinal surgery. The second patient was a 49-year-old man who had tenderness to palpation and drainage at the spinal surgical site. The last one was a 72-year-old man presented with was high fever, chills and pain. They were diagnosed surgical site infection after spinal surgery and treated successfully with ultrasoundguided aspiration.

Conclusion: Those cases illustrate the ultrasound-guided aspirating incisional effusion holds promise as a simple and safe technique for surgical site infection after spinal surgery.

Keywords: Postoperative Surgical Site Infection; Spinal Surgery; Ultrasound-Guided Aspiration; Case Report

\section{Introduction}

Surgical site infection (SSI) is a common and dreaded complication after posterior spinal surgery. Reported risk factors for infection include patient factors such as age, male sex, diabetes, obesity, smoking, malnutrition and being immunocompromised, as well as intraoperative factors such as long operation time, blood transfusions, open surgery, a greater number of levels operated on and employment of intraoperative equipment including microscopes or CT [1-3]. The infection following spinal instrumentation remains a challenging and controversial subject, as it is positively associated with prolonged hospitalization, increased healthcare costs and rate of reoperation, poorer longterm outcomes, and greater dissatisfaction with the initial surgery [4-7]. To treat SSI, surgical removal of internal fixation is sometimes required, although the loss of fixation can contribute to spinal instability [8-11]. CT-guided aspiration and drainage and drainage is a useful treatment that drains exudates, pus and necrotic tissue to reduce the chance of wound bacterial growth [12]. But these cases required multiple treatments that increased radiation and expenditure. Compared with CT, ultrasound imaging has its unique advantages: non-electromagnetic radiation, economical and convenient. Here, we report three cases of SSI of posterior spine surgery with aspiration under ultrasound guidance was successfully used to promote wound healing.

\section{Case Reports}

This study aimed to report the cases of three patients of infection after spinal surgery who underwent ultrasound-guided aspirating incisional effusion (Table 1). The cases we reported here all wrote informed consent for publication of anesthesia. 
Table 1: Therapies in infection patients.

\begin{tabular}{|c|c|c|c|c|c|c|c|c|c|}
\hline Cases & $\operatorname{Age}(y)$ & Sex & Surgery & $\begin{array}{c}\text { VSD } \\
\text { duration } \\
\text { days }\end{array}$ & $\begin{array}{l}\text { IV antibiotic } \\
\text { used in turn }\end{array}$ & $\begin{array}{l}\text { Duration of } \\
\text { IV antibiotic } \\
\text { therapy (days) }\end{array}$ & $\begin{array}{l}\text { Number of } \\
\text { aspiration }\end{array}$ & $\begin{array}{c}\text { Volume of } \\
\text { aspiration }(\mathrm{ml})\end{array}$ & $\begin{array}{c}\text { post-operative } \\
\text { hospital length } \\
\text { of stay (days) }\end{array}$ \\
\hline 1 & 79 & $\mathrm{~F}$ & $\begin{array}{l}\text { posterior } \\
\text { spinal L4, } \\
\text { L5, and } \\
\text { S1 pedicle } \\
\text { screw } \\
\text { fixation }\end{array}$ & 3 & $\begin{array}{l}\text { cefuroxime } \\
\text { ceftriaxone } \\
\text { cefoperazone } \\
\text { vancomycin }\end{array}$ & 24 & 1 & 15 & 34 \\
\hline 2 & 49 & M & $\begin{array}{c}\text { posterior } \\
\text { spinal T8- } \\
\text { T12 total } \\
\text { laminectomy } \\
\text { and pedicle } \\
\text { screw } \\
\text { fixation }\end{array}$ & 0 & $\begin{array}{l}\text { cefuroxime } \\
\text { sodium, } \\
\text { sulperazone, } \\
\text { ceftriaxone } \\
\text { vancomycin }\end{array}$ & 31 & 3 & $\begin{array}{c}220 \\
(80+100+40)\end{array}$ & 40 \\
\hline 3 & 72 & M & $\begin{array}{c}\text { posterior } \\
\text { spinal } \\
\text { L4-L5 total } \\
\text { laminectomy } \\
\text { and pedicle } \\
\text { screw } \\
\text { fixation }\end{array}$ & 0 & $\begin{array}{c}\text { cefuroxime } \\
\text { sulperazone, } \\
\text { moxifloxacin, } \\
\text { ceftriaxone } \\
\text { talentview } \\
\text { amikacin }\end{array}$ & 13 & 2 & $60(30+30)$ & 23 \\
\hline
\end{tabular}

Note: F: female; M: male; VSD: vacuum sealing drainage; IV: intravenous.

\section{Case 1}

History and Examination. A 79-year-old woman with several years of low-back pain that radiated to her feet was described. She had tried conservative management using pain medications or acupuncture but the pain continued. On examination she had hallux dorsiflexion muscle IV level. Superficial sensation was impaired over the lower legs and lateral dorsum of feet. Meanwhile she had a positive straight leg-raise test at $60^{\circ}$. An MRI study of her lumbar spine revealed L4-L5, L5-S1 para-central disc herniation. The patient also had a history of hypertension and diabetes that required chronic, long-term medication.

Operation: This woman underwent posterior spinal L4, L5, and S1 pedicle screw fixation. Her pain improved obviously and ended the treatment of vacuum sealing drainage (VSD) on the third postoperative day. The patient received 1 intravenous antibiotics (cefuroxime) $30 \mathrm{~min}$ preoperatively, and 5 additional doses during 5 days postoperatively, then ceftriaxone replaced. Fifteen days after the operation, the patient presented increased low-back pain. Laboratory tests: white blood cell count (WBC): 7.7 10^9/L (normal range 4-10 10^9/L), neutrophils\% NE\%: 51.2\% (normal range 50-70\%), hypersensitive $\mathrm{C}$-reactive protein (HS-CRP): 41.58 $\mathrm{mg} / \mathrm{L}$ (normal range 0-3 $\mathrm{mg} / \mathrm{L}$ ), erythrocyte sedimentation rate (ESR): $103 \mathrm{~mm} / \mathrm{h}$ (normal range $0-15 \% \mathrm{~mm} / \mathrm{h}$ ) (Figure 1). Three days after vancomycin treatment, the pain was unremitting and the HS-CRP and ESR were still higher then normal. Procedure under ultrasound guidance. The patient was placed in a right lateral position and a low-frequency linear ultrasound transducer was placed in a longitudinal orientation lateral to the L4-S1 spinous process. Incisional effusion was identified. A tuohy needle was used to tap $15 \mathrm{ml}$ of dark brown fluid. Post-procedural Course. This woman was treated vancomycin 4 days after the procedure, and experienced immediate improvement in her low-back pain. Fifteen days later, she was discharged home.

\section{Case 2}

History and Examination. A 49-year-old man was referred to the hospital with a 2-year history of low-back pain and a 4-month history of lower limb weakness. An MRI study founded that he had the thickening of ligamentum flavum (TLF) in the L4-L5 and thoracic spinal cord compression.

Operation: This patient was performed posterior spinal L4L5 total laminectomy and pedicle screw fixation. Six days after the operation, he had tenderness to palpation and drainage at the surgical site. Laboratory tests: WBC: $16.510^{\wedge} 9 / \mathrm{L}, \mathrm{NE} \%$ : 82.7\%, HSCRP: $5.18 \mathrm{mg} / \mathrm{L}$, ESR: $13 \mathrm{~mm} / \mathrm{h}$ (Figure 2). First procedure under ultrasound guidance. Similar to the procedure in the first patient, $80 \mathrm{ml}$ of pink fluid was tapped from superficial plane to the erector spine muscle (ESM) under the ultrasound guided. After 10min, the patient reported that his pain had diminished significantly. Second procedure under ultrasound guidance. His pain aggravated gradually in a week. Laboratory tests showed that WBC and NE\%have dropped off, but HS-CRP and ESR have gone up. A large 
amount of effusion in the surgery site was confirmed again by ultrasound. We drained $100 \mathrm{ml}$ of pink fluid this time. The antibiotic changed from ceftriaxone to vancomycin. Third procedure under ultrasound guidance. Four days later, this man told that his pain had alleviated. The visualized effusion decreased and only $40 \mathrm{ml}$ of pink fluid was tapped. Post-procedural Course. Eighteen days after the third procedure there was no sign of infection, and the pain was resolved. Then the man was discharged home.

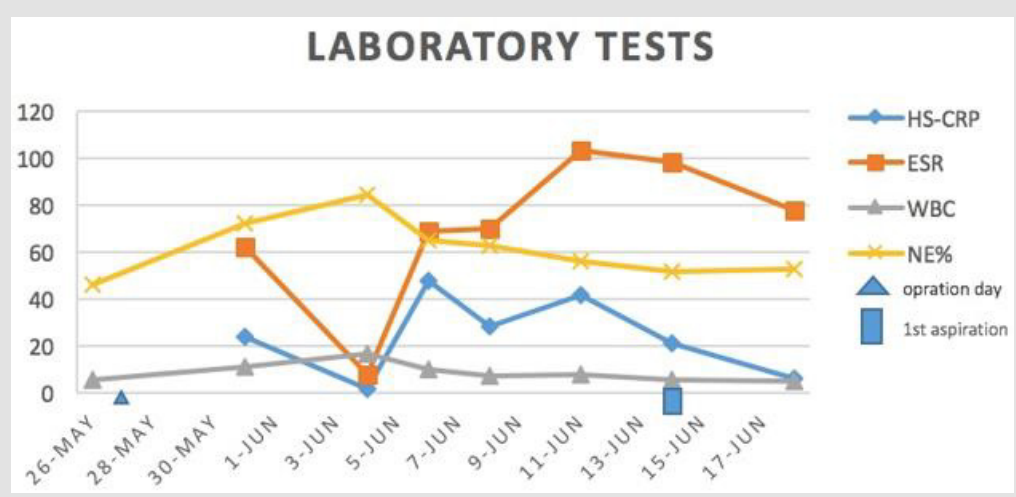

Figure 1: The trend chart of laboratory tests which were related to infections of the first case during perioperative period.

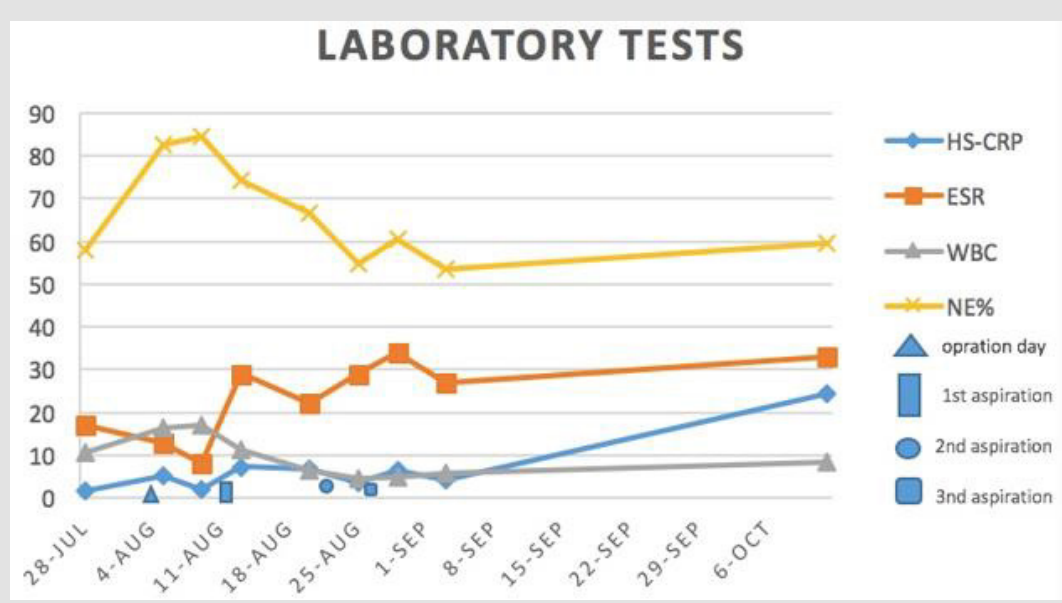

Figure 2: The trend chart of laboratory tests which were related to infections of the second case during perioperative period.

\section{Case 3}

History and Operation. A 72-year-old man, complained of severe low-back pain that radiated to his right feet. He was performed posterior spinal L4-L5 total laminectomy and pedicle screw fixation. A week after the operation, he was racked by high fever $\left(40.1^{\circ} \mathrm{C}\right)$, chills and pain at the surgical site. Laboratory tests: WBC: 3.5 10^9/L, NE\%: 79.7\%, HS-CRP: 112.63 mg/L, ESR: $97 \mathrm{~mm} / \mathrm{h}$, PCT: $27.88 \mathrm{ng} / \mathrm{ml}$ (Figure 3). During the four days, although sulperazone and amikacin was used, the infection had maintained. First procedure under ultrasound guidance. Similar to the above-mentioned procedure, ultrasound was used to guide access to the area lateral to the lumbar spinous process and 30 $\mathrm{ml}$ of pink fluid was drained (Figure 4). Second procedure under ultrasound guidance. His temperature decreased to normal, but the pain continued. Laboratory tests: WBC: 7.2 10^9/L, NE\%: 70.3\%, HS-CRP: $50.97 \mathrm{mg} / \mathrm{L}$, ESR: $45 \mathrm{~mm} / \mathrm{h}$, PCT: $2.03 \mathrm{ng} / \mathrm{ml}$ (Figure 3). Ultrasonography study was used to determined the effusion, and $30 \mathrm{ml}$ of dark brown fluid was drained (Figure 5). Post-procedural Course. The day after the procedure, the patient experienced immediate improvement in his pain. He was discharged home 7 days after the second aspiration and at his follow- up evaluation nearly 1 month later had continued resolution of his symptoms (Figure 6). 


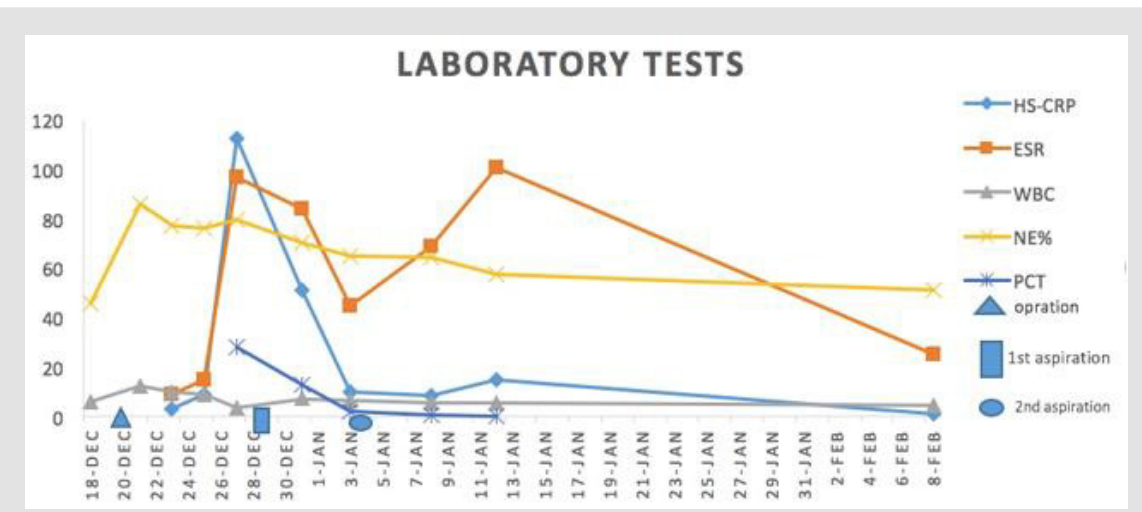

Figure 3: The trend chart of laboratory tests which were related to infections of the third case during perioperative period.

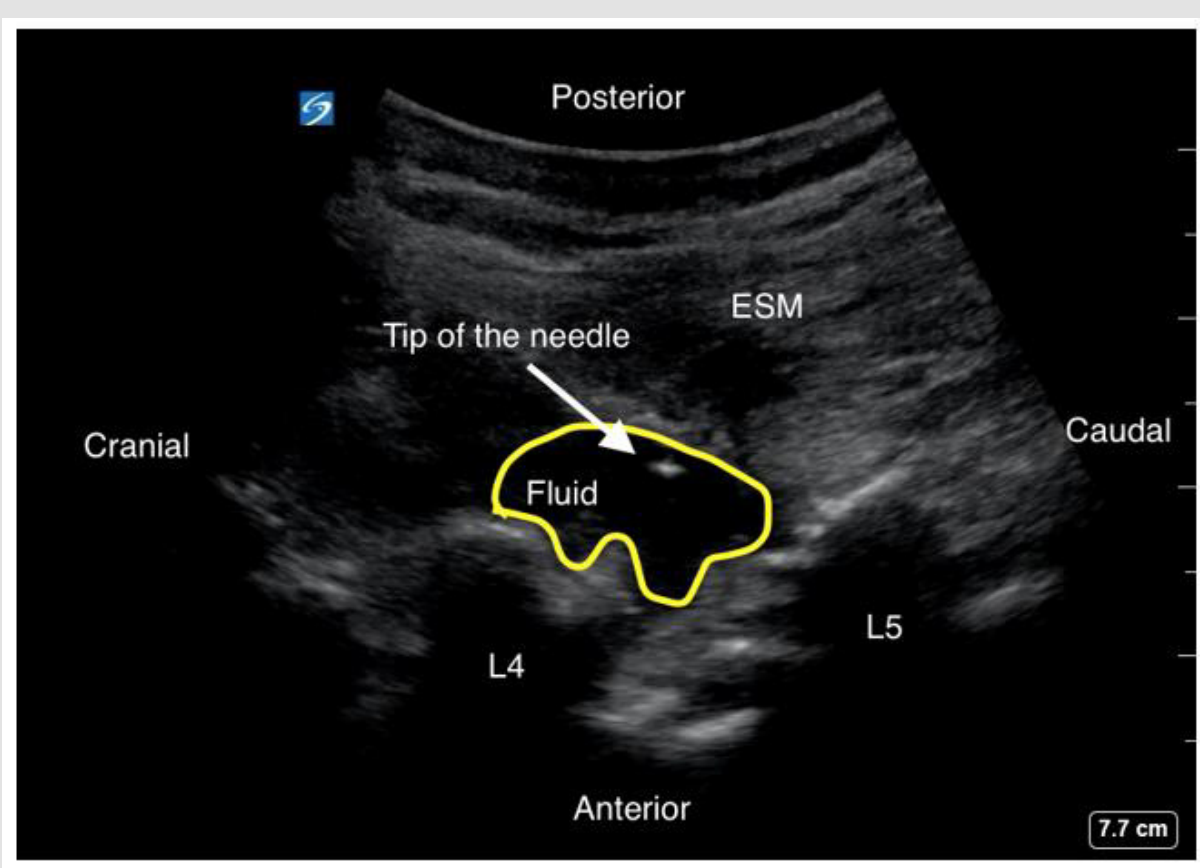

Figure 4: Ultrasound image of aspiration in the level of L4-L5. Arrowheads indicate the tip of needle. ESM: erector spine muscle.

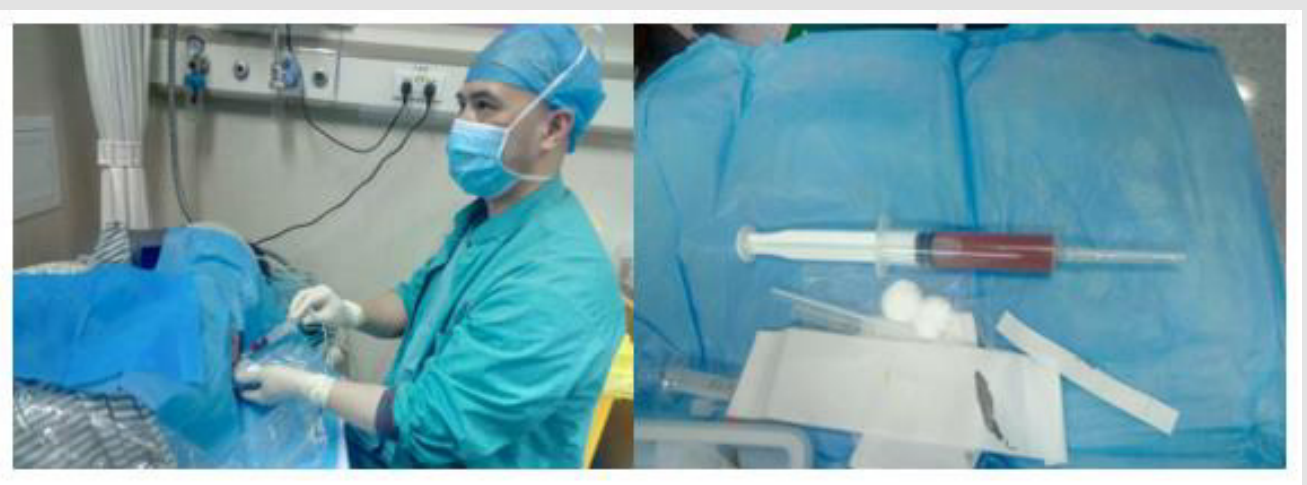

Figure 5: Dark brown fluid was drained under ultrasound guidance. 


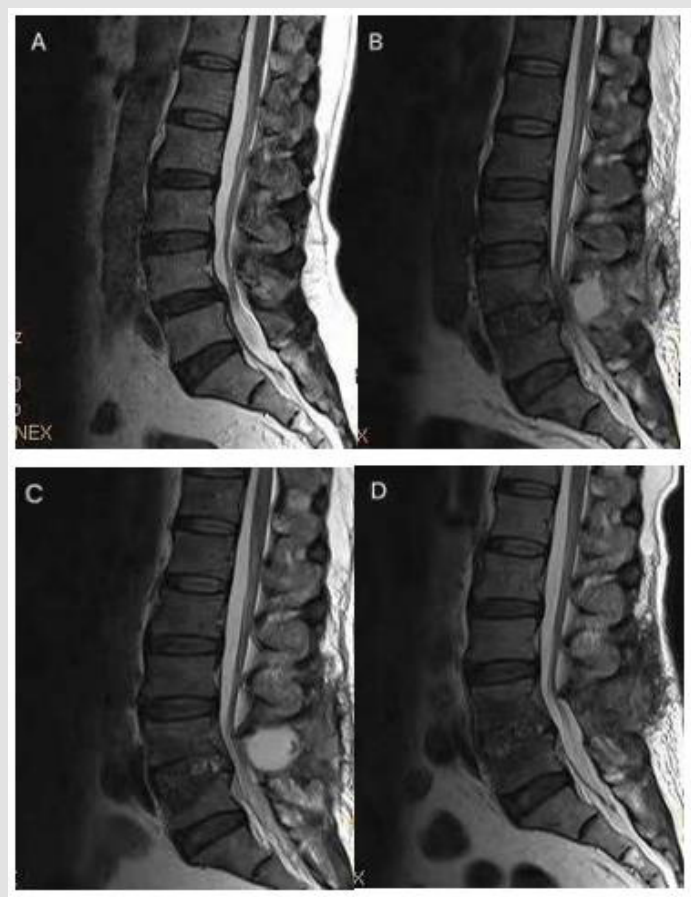

Figure 7: MRI studies.

A. Preoperative MIR graph of the patient's spine showing L4-L5 intervertebral disc bulges around and the compression of dura mater.

B. Image at the level of L4-L5 showing that a signal of mixed before the first procedure.

C. Before the second procedure graph showing the area of signal mixed changed large.

D. Image of the patient's follow-up evaluation nearly 1 month after the discharge showing that the mixed signal area had disappeared.

\section{Discussion}

Spinal operation is commonly used in the therapy for spinal disease. Post-operative surgical site infection is a dreadful complication with reported rates ranging from $0.7-20 \%$ [1-5]. At present, there are many modalities being used for therapy including antibiotic, vacuum sealing drainage (VSD), instrumentation removal, debridement and continuous irrigation and suction [1114]. There remains no consensus on indications for maintenance of the stabilization devices versus removal. These devices are often removed to facilitate infection control for the bacteria associated with these infections form biofilms attached to the internal fixator. However, reoperation means higher costs, more pain and longer hospital stay. Studies showed that significant loss of correction in deformity patients after instrumentation removal, even if stable fusion was observed. In our report described here, after undergoing posterior spinal surgery three patients developed SSI. By aspirating incisional effusion with ultrasound-guidance and retaining stabilization devices, their symptoms, the risk of spinal instability and neurological risks decreased, resulting in increased quality of life.
It is widely agreed that deep infection should be managed with aspiration drains pus, and necrotic tissues that can hinder the antiinfective function of para-spinal muscle and granulation tissues. Vacuum sealing drainage (VSD) is a negative-pressure technique, which can achieve safe and rapid healing of soft wounds and infections. However, these patients $[13,14]$ required wound opening during the VSD treatment and a second surgery to close the wound, which increased patient discomfort and the expense, limited patient activity, and required advanced medical facilities. Comparing to VSD, ultrasound-guided aspiration has more advantage including small trauma, less pain, economical and convenient. In our institution we operated 1258 patients of degenerative disc diseases from June 2015-February 2018. There were 1040 patients of posterior spinal surgery. Of these 1040 discs, 115 cases (1.1\%) suffered the surgical site infection. Some cases with less severe infection and few effusion could be treated with several weeks of antibiotics. Ultrasound-guided aspirating incisional effusion was performed in those patients whose infection has progressed on MRI despite appropriate antibiotic therapy. Twenty cases undergone this procedure, which all of them have received satisfactory effect. For 
other cases with severe infection including suppurative spondylitis and septicaemia, aspiration alone cannot completely eliminate bacteria and suggests that surgery was an effective option. For these cases, ultrasound-guided aspiration could help to identify the effusion and correctly choose and use antibiotics.

\section{Conclusion}

Based on our small experience with postoperative surgical site infection after spine surgery, we recommended an ultrasonography study to determine the effusion, to determine the infection, to determine causative organisms, to choose correct antibiotic and to aspirate effusion.

\section{Conflicts of Interest/Disclosures}

The authors assert that they have no financial or other conflicts of interest in relation to this research and its publication.

\section{References}

1. Linam WM, Margolis PA, Staat MA, Britto MT, Hornung R, et al. (2009) Risk factors associated with surgical site infection after pediatric posterior spinal fusion procedure. Infect Control Hosp Epidemiol 30(2) 109-116.

2. Fang A, Hu SS, Endres N, Bradford DS (2005) Risk factors for infection after spinal surgery. Spine 30(12): 1460-1465.

3. Kasliwal MK, Tan LA, Traynelis VC (2013) Infection with spinal instrumentation: Review of pathogenesis, diagnosis, prevention, and management. Surgical Neurology International 4(5): S392-S403.

4. Hegde V, Meredith D S, Kepler C K, Huang RC (2012) Management of postoperative spinal infections. World Journal of Orthopedics 3(11): 182-189.

\section{ISSN: 2574-1241}

DOI: 10.26717/BJSTR.2021.39.006275

Chuiliang Liu. Biomed J Sci \& Tech Res

(C) (P) This work is licensed under Creative

Submission Link: https://biomedres.us/submit-manuscript.php
5. Pawar AY, Biswas SK (2016) Postoperative Spine Infections. Asian spine journal 10(1): 176-183.

6. Maruo K, Berven SH (2014) Outcome and treatment of postoperative spine surgical site infections: predictors of treatment success and failure. Journal of Orthopaedic Science 19(3): 398-404.

7. Rihn JA, Kurd M, Hilibrand AS, Lurie J, Zhao W, et al. (2013) The Influence of Obesity on the Outcome of Treatment of Lumbar Disc Herniation. The Journal of Bone and Joint Surgery (American) 95: 1.

8. Rasouli MR, Viola J, Maltenfort MG, Shahi A, Parvizi J, et al. (2015) Hardware removal due to infection after open reduction and internal fixation: trends and predictors. Arch Bone Joint Surg 3(3): 184-192.

9. Picada R, Winter RB, Lonstein JE, Denis F, Pinto MR, et al. (2000) Postoperative deep wound infection in adults after posterior lumbosacral spine fusion with instrumentation: incidence and management. Spinal Disord 13(1): 42-45.

10. Cahill PJ, Warnick DE, Lee MJ, Gaughan J, Vogel LE, et al. (2010) Infection after spinal fusion for pediatric spinal deformity: thirty years of experience at a single institution. Spine 35(12): 1211-1217.

11. Ho C, Skaggs DL, Weiss JM, Tolo VT (2007) Management of infection after instrumented posterior spine fusion in pediatric scoliosis. Spine 32(24): 2739-2744.

12. Pull ter Gunne AF, Mohamed AS, Skolasky RL, Van Laar- hoven CJ, Cohen DB (2010) The presentation, incidence, etiology, and treatment of surgical site infections after spinal surgery. Spine 35(13): 1323-1328.

13. Kale M, Padalkar P, Mehta V (2017) Vacuum-assisted closure in patients with post-operative infections after instrumented spine surgery: a series of 12 cases. Orthop Case Report 7(1): 95-100.

14. Zhang H, Li Q (2018) Improved vacuum sealing drainage for treatment of surgical site infection following posterior spinal internal fixation: A case report. Medicine 97(7): e9952.

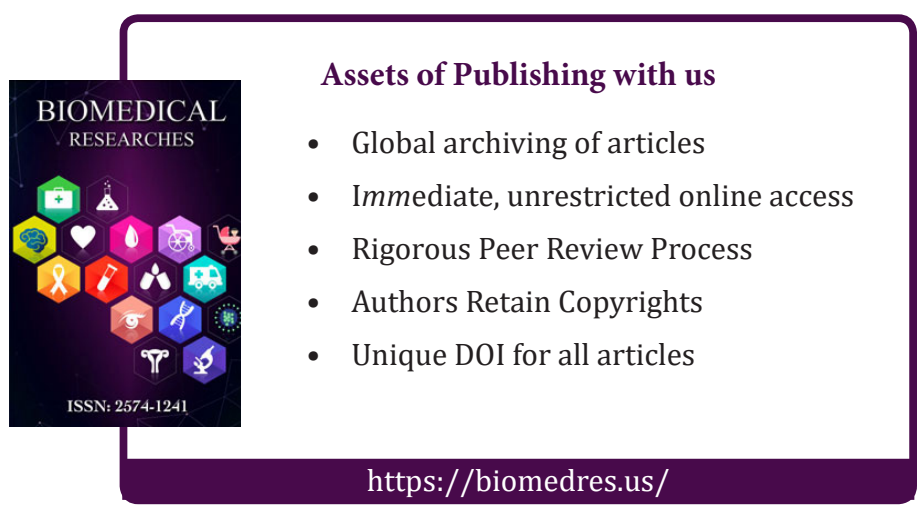

